\title{
The Contribution of Poultry, Swine and Rabbit Production to the Short-term Solution of Meat Scarcity in Nigeria
}

\author{
By \\ F. C. Овіона, \\ Department of Animal Science, \\ University of Nigeria, \\ Nsukka.
}

\section{SUMMARY}

THE current public concern about meat shortage in Nigeria is a clear indication that the endemic animal protein deficiency which Nutritionists had long diagnosed at the nutrient level, is now being felt at the commodity level. Estimates on the animal protein intake in Nigeria vary between $7 \mathrm{gm}$ and $8.27 \mathrm{gm}$. A short-term strategy to narrow this gap has to involve a rapid expansion in the production of those farm animals which are known to possess a high level of biological and economic efficiency in their production. Other important considerations are fecundity, maturity rate, generation interval and general acceptability of the animal products. From these considerations poultry, pigs and rabbits emerge as having unquestionable propensity for this objective. Proposals are made for the immediate establishment of an urban poultry in every state and urban piggeries in ten southern states of Nigeria. These additional sources of animal protein are estimated to add about $2 \mathrm{gm}$ to the present animal protein intake, and as such cannot be claimed to provide all the solutions. Other potent sources of animal protein, particularly the importation of dry fish should be expanded Above all, the Governments of the Federation should explore means of involving the masses in the production of their own meat along similar lines with the poultry revolution of the early sixties in the then Eastern Region or the current food drive in Bendel State.

\section{BACKGROUND}

Meat, defined in the broad context of edible animal products, is widely recognised and accepted as the ultimate indicator of dietary quality. Meat is relished by most people in the world to the extent that an individual would normally consume as much meat as he can afford. Thus meat is the most limiting and expensive item in the diet. For example, in a free buffet situation, people are apt to go for more meat than they could normally afford to consume and less starch foods than they would normally have to eat.
These basic attributes of scarcity, essentiality, delicacy and demand account for a wide price separation between animal and plant products in any part of the world.

Meat scarcity has strong biological, economic and sociological basis. Biologically, animals are by far less efficient converters of nitrogen into protein than plants. For example, while plants can convert soil or fertilizer nitrogen to plant protein with $50 \%$ efficiency, the efficiency of animal conversion of feed nitrogen is $8 \%$ as beef, $17 \%$ as pork, $23 \%$ as eggs, $24 \%$ as broilers and $30 \%$ as milk. $\left({ }^{3}\right)$ Again plants are more productive in terms of output of dry matter per hectare than animals. A maize or bean seed can reproduce its weight at least a hundred-fold in a period of six months whereas the most fecund farm animal can hardly quadruple its weight in the same period. Viewed another way, a hectare of productive land can provide a man's protein requirements for 190 days as beef, 583 days as milk and as much as 5,496 days as soya bean protein. These examples illustrate and explain in part, the relative preponderance of plant over animal components in nature, in the market and in the diet.

In the Nigerian situation there are additional climatic and ecological factors which constitute serious constraints to the national meat production through their influences on

1. The national herd size

2. Animal Productivity and

3. The national herd management.

It is not intended in this paper to go into these constraints in any detail; rather it would serve as useful purpose to attempt 
an up-to-date national meat inventory if only to estimate the animal protein gap that needs to be closed in the short run.

In the absence of a national livestock census that would provide an accurate livestock population in Nigeria an average of three independent sources is used here to derive an annual meat supply figure for Nigeria(4). Table 1 gives the livestock population, meat yield and animal protein yield from the various sources except wildlife. On the basis of a national population of 80 million, average consumption of animal protein is currently estimated at $8.27 \mathrm{gm}$ per caput per day. This figure is higher than the $7 \mathrm{gm}$ computed by the Federal Ministry of Economic Development and Reconstruction $\left({ }^{2}\right)$ or the $7.5 \mathrm{gm}$ estimated by Oyenuga in 1975, $\left({ }^{7}\right)$ and represents a short fall of $19.73 \mathrm{gm}$ from the minimum requirement of $28 \mathrm{gm}$ per caput per day. In other words Nigerians are still consuming less than $30 \%$ of their minimum requirement for animal protein.

Nutritionists and Demographers have been aware of this animal protein gap in the Nigerian diet for many years and have incessantly drawn the attention of the government of the day to its implications through numerous resolutions, publications, representations and public state- ments. The current public concern is merely a recognition, at the commodity level, of an existing situation which has been hightened by four main factors that have recent history.

1. The drought of 1973 was disastrous not only from the immediate loss of some 480,000 heads of cattle but from the prolonged effect of losses of the offspring that would have accrued from them. For example, assuming a 50-50 sex ratio, a meagre $60 \%$ calf crop and $10 \%$ mortality, the 480,000 herd lost in 1973 would have appreciated by the end of 1975 to some 870,000 comprising 729,000 adults, 120,000 yearlings and 30,000 young calves.

2. The Post-Jangali reaction which resulted in the recession of import trade cattle involving about $30 \%$ of the slaughter cattle in Nigeria from the neighbouring countries of Chad, Niger and the Cameroons.

3. The unabated population growth which is not matched by a revolutionary increase in animal protein output, and

4. A world-wide inflation that has affected every available commodity in the market.

TABLE 1

Livestock Population and Animal Protein Yield

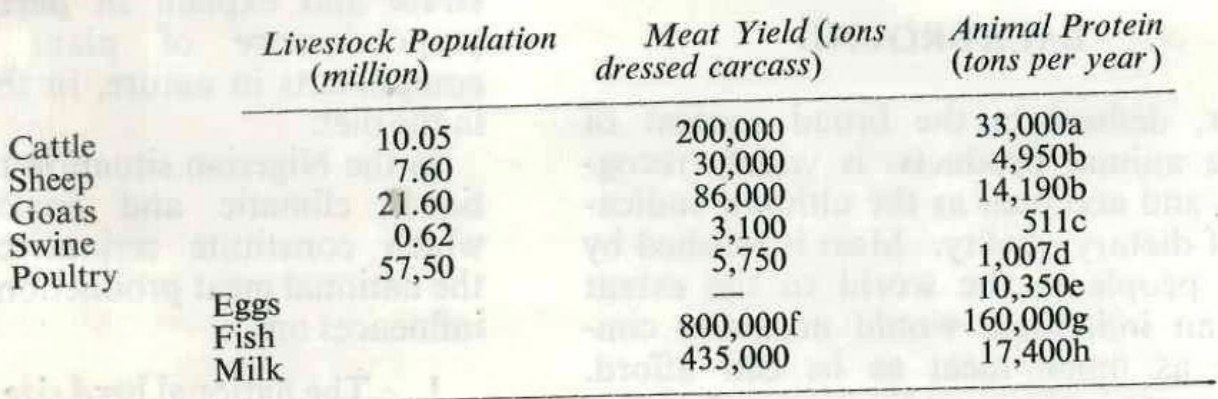

O Mean of three independent sources

a At $10 \%$ off-take, $16.5 \%$ protein

b , ,

" $50 \mathrm{~kg} \mathrm{,} \mathrm{,} \mathrm{,}$

c " " " $\quad 1$ kg dressed carcass, $17.5 \%$ protein,

At 30 eggs per year hen, 6 gm protein per egg

Fresh fish equivalent

$33 \%$ dry matter, $60 \%$ protein,

h $\quad 4 \%$ protein. 


\section{Accelerated Meat Production}

An accelerated meat production programme as an answer to the current meat shortage in Nigeria should be one that would aim at providing an additional 576,116 tons of animal protein per annum. Considering that this figure is about $143 \%$ of the current consumption level, the programme would have to be very ambitious, and should have a short-term maturity to discourage a further depletion of the national herd population by a continued high rate of slaughter off-take.

The choice of species for a short-term meat supply programme should take into account not only the rate of growth and maturity of the species but also -

1. Generation interval,

2. Fecundity in terms of litter size; Prolificacy in terms of number of offspring in a given time,

3. Yield and turn-over of animal protein

4. Biological efficiency

5. Acceptability

6. Nutritive value.

Table 2 shows a comparative growth and reproductive performance for a number of livestock species. From this table it can be seen that cattle and to some extent sheep, are disqualified from considerations of short term meat production on the basis of rate of maturity, generation interval and fecundity.

Another consideration is Biological Efficiency which can be applied in this case to denote the efficiency of meat or animal protein production. Biological efficiency can be viewed as yield of a biological product from a given unit of input or as economic benefits derived from the biological process $\left({ }^{3}\right)$. In either case a comparison of farm animals shows remarkable differences in this parameter. From a study of the comparative biological efficiency of cattle, goats, pigs, poultry and rabbits, Okwuosa $\left({ }^{6}\right)$ observed that pigs were the most efficient in terms of cumulative amount of edible protein produced after five years but the least efficient in terms of the cumulative profit after 5 years. Table 3 gives a summary of these data: From this table the species rank as follows: pigs, poultry, rabbits, goats and cattle from the standpoint of biological efficiency per se, while from the standpoint of economic efficiency they rank as goats, poultry, cattle, rabbits and pigs.

TABle 2

\section{Reproduction Data of Farm Animals}

\begin{tabular}{lcc} 
Species & Generation Interval & Offspring/year \\
Cattle & 350 days & 0.85 \\
Sheep \& Goats & 200 days & 2 \\
Pigs & 156 days & 18 \\
Rabbits & 85 days & 24 \\
Poultry & - & 180 \\
\hline
\end{tabular}

TABLE 3

Comparative Biological and Economic Efficiency of Livestock using Cattle as Standard

\begin{tabular}{lrrrrr} 
& Cattle & Pigs & Goats & Rabbits & Chicken \\
\hline $\begin{array}{l}\text { Cummulative Profit after } \\
5 \text { years }\end{array}$ & $N 6,659$ & 4,806 & 49,937 & 5,972 & 8,406 \\
$\begin{array}{l}\text { Cumulative amount of } \\
\text { edible protein after 5 years } \\
\text { (tons) }\end{array}$ & 100 & 72 & 794 & 90 & 126 \\
\hline
\end{tabular}


This table agrees with the widespread view that non-ruminants yield the highest turnover of animal protein per animal unit. It should also be noted that these same species namely poultry, pigs and rabbits require relatively less capital investment and lend themselves to small capital operators.

\section{Poultry}

Poultry is the most prolific of all farm animals, being capable of producing up to 200 eggs or offspring per year. The successful adaptation of exotic poultry breed in Nigeria and the proliferation of poultry enterprises have resulted in the accumulation of a reasonable amount of data on production coefficient of the various poultry enterprises. Studies carried out at the Agricultural Development Authority of the former East Central State(5) indicate that an integrated hatchery, breeding and broiler enterprise standardised on a 70 week production cycle is capable of generating up to 2.8 million day old chicks, 1.4 million broilers and 1.4 million pullets at an average profit of $₹ 2,765$ per week. There is no obvious reason why each of the 19 states of Nigeria cannot embark on a crash urban poultry scheme of 1 million broilers and 1 million layer capacity. According to Jakonda $\left({ }^{4}\right)$, the current cereal supply in the country is capable of feeding 40 million layers, 80 million broilers and 0.5 million porkers. The recent ban on exportation of groundnut cake has resulted in a slumping of the price to as low as $\$ 65.00$ per ton ex Sokoto. The urgent need for 19 urban poultry centres across the country is strongly indicated.

\section{Pigs}

Pigs have the highest efficiency in terms of the amount of edible protein produced per unit of time, although they also have the least cummulative profit. Expansion in swine production should follow the same lines suggested for poultry except that pigs should be confined to urban centres in the Southern half of the country owing to Religious taboo for pork. Another problem encountered with swine production is the problem of marketing.
This is ironical in our circumstances. The only solution can be found in improved distribution, storage and processing. At this stage in our development government and private investors should begin to consider the feasibility of establishing urban refrigerated lockers for public rental.

Establishment of 10 piggeries in 10 southern states each with a capacity of 10,000 sow unit is estimated to yield 17,500 tons of animal protein annually. The combined yield of animal protein from both the urban piggeries and the poultry centres is estimated at around 49,160 tons per year, enough to increase the average national animal protein intake by about $2 \mathrm{gm} /$ caput/day.

\section{Rabbits}

Although rabbits have a reasonably high biological efficiency as converters of herbage to animal protein, the acceptability of rabbit meat is yet to be a household word.

\section{REFERENCES}

Agricultural Development of Nigeria-19651980. FAO, Rome. 1965.

Federal Ministry of Economic Development 1975. The Third National Development PLAN 1975-1980.

JONES, J.G.W. 1973. The biological efficiency of protein production. Cambridge University Press.

JAKONDA, S.Z. 1975. Improvement in Livestock Production: Nutrition and Feeds. Nigerian J. Anim. Prod. Vol.2, No. 1. 12-21.

Овіона, F.C. 1975. Meat Outlook in Nigeria. The Cardoso. J. Ag. Student Council UNN Vol. 1. No. 1.

Okwuosa, B. N. 1974. Animal Production in the Zaire in: Oxfam-Second Report of the Oxfam Team of Advisers. PP. 26-56

OYENUGA, V.A. 1975. The Challenge of 1980 in Nigerian Agriculture (Livestock) Sector. Nigerian J. Anim. Prod. Vol. 2, No. 1. 71-11 